\title{
Gasteroid mycobiota of Rio Grande do Sul, Brazil: Lycoperdon and Vascellum
}

\author{
Cortez VG ${ }^{1}$, Baseia $\mathrm{IG}^{2}$ and Silveira $\mathrm{RMB}^{3}$ \\ ${ }^{1}$ Universidade Federal do Paraná, Campus Palotina, Palotina, PR, Brazil \\ ${ }^{2}$ Universidade Federal do Rio Grande do Norte, Depto. de Botânica, Ecologia e Zoologia, Natal, RN, Brazil \\ ${ }^{3}$ Universidade Federal do Rio Grande do Sul, Depto. de Botânica, Porto Alegre, RS, Brazil
}

Cortez VG, Baseia IG, Silveira RMB 2013 - Gasteroid mycobiota of Rio Grande do Sul, Brazil: Lycoperdon and Vascellum. Mycosphere 4(4), 745-758, Doi 10.5943/mycosphere/4/4/11

\begin{abstract}
The diversity of Lycoperdon and Vascellum in the mycobiota of Rio Grande do Sul State, in southern Brazil, was investigated. These genera are considered distinct due to structure of the subgleba, presence/absence of paracapillitium and of a diaphragm. After a study of fresh and herbarium specimens, the following species were identified in the area: Lycoperdon juruense, $L$. lividum, L. marginatum, L. ovoidisporum, L. perlatum, Vascellum hyalinum, and V. pratense. Detailed descriptions of the species are accompanied by photographs of the basidiomata, line drawings of the microstructures, and scanning electron microscopy of the basidiospores.
\end{abstract}

Key words - Agaricales - Agaricomycetes - Lycoperdaceae - puffballs - taxonomy

\section{Introduction}

Lycoperdaceae Chevall. (Agaricales, Agaricomycetes) comprises a large family of puffballs with worldwide distribution. In spite of this, the group is little known in the Neotropical region, except for a few genera monographed (Homrich \& Wright 1973, 1988, Wright \& Suárez 1990, Suárez \& Wright 1996). Similarly, the Lycoperdaceae from southern Brazil have been poorly investigated since Rick (1930, 1961), Homrich (1969) and Homrich \& Wright (1973, 1988). In the last years, some species were reported from the states of Paraná (Meijer 2006) and Rio Grande do Sul (Guerrero \& Homrich 1999, Sobestiansky 2005, Cortez et al. 2007, 2008a).

As part of a revision of the gasteroid fungi from the state of Rio Grande do Sul, the lycoperdaceous fungi were surveyed (Cortez et al. 2009, 2010, 2011a,b, 2012) and partial results are presented here. In this paper, the genera Lycoperdon Pers. and Vascellum F. Šmarda are revised. Both genera belong to a group of gasteroid fungi sharing several morphological features, but differ in the structure of the peridium and subgleba, presence of a diaphragm separating the gleba from the subgleba and nature of the capillitium (Miller \& Miller 1988). Several mycologists stated the importance of these features at the generic level (Zeller 1948, Smith 1951, Kreisel \& Dring 1967, Ponce de Leon 1970, Kreisel 1993), while others regard them to an infrageneric status (Larsson \& Jeppson 2008). Molecular studies have provided new data and helped to elucidate taxonomic concepts in some cases (Krüger et al. 2001, Vellinga 2004, Krüger \& Gargas 2008, Larsson \& Jeppson 2008, Bates et al. 2009) but, unfortunately, they are limited to European and North American taxa. Thus, Lycoperdon and Vascellum are here considered as distinct genera, until additional data including Neotropical taxa are considered to a better knowledge of their phylogeny. 


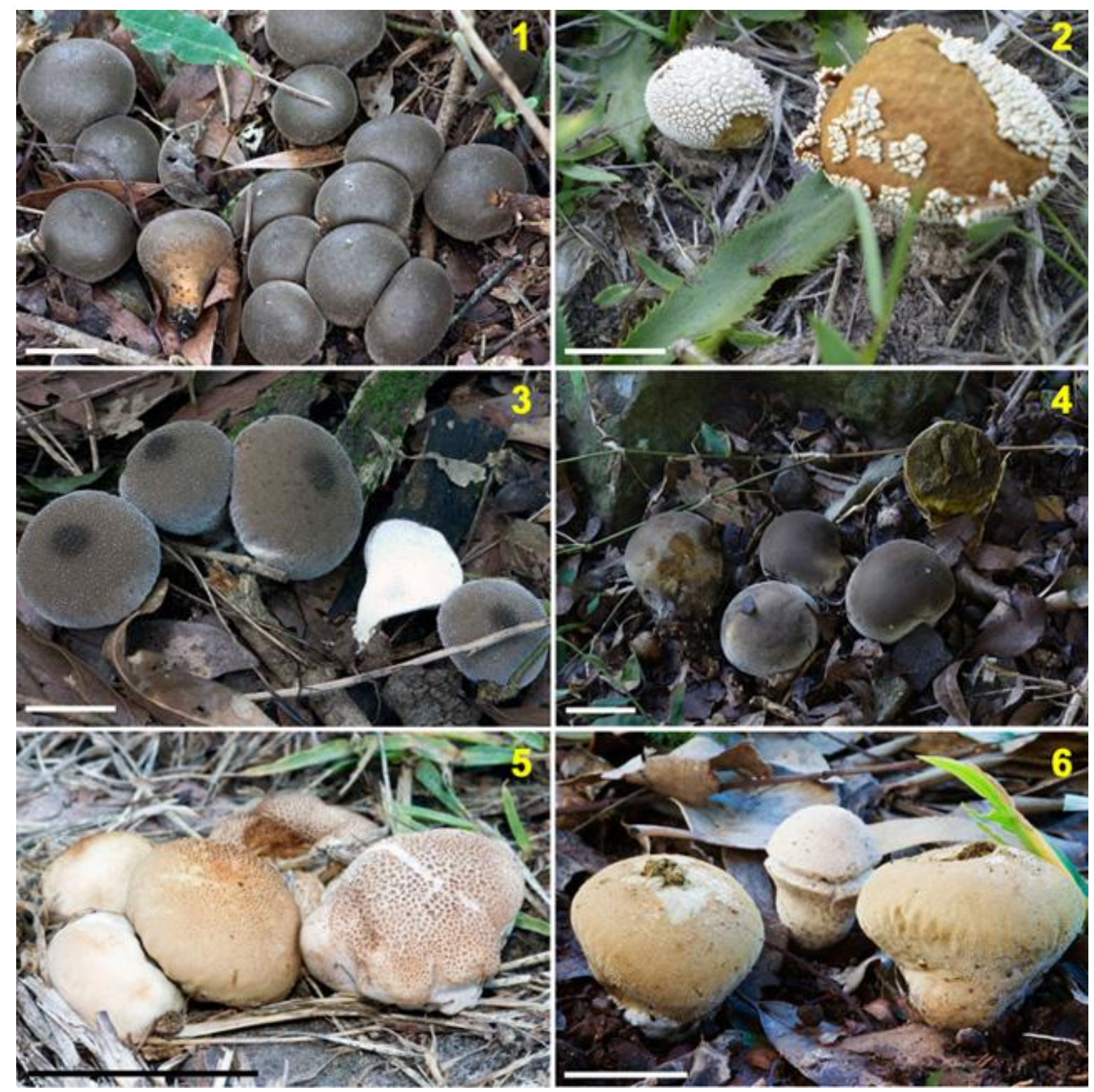

Figs 1-6 - Basidiomata of Lycoperdon and Vascellum. 1 Lycoperdon juruense. 2 L. marginatum. 3 L. perlatum. 4 L. ovoidisporum. 5 Vascellum hyalinum. 6 V. pratense. Scale bar: $20 \mathrm{~mm}$.

\section{Materials \& Methods}

Specimens were gathered from March 2006 to May 2009 during several trips to Rio Grande do Sul, the southernmost Brazilian State. In addition, specimens from the following herbaria were revised (abbreviations following Index Herbariorum): BAFC, HURG, ICN, PACA, PEL, SMDB, and SP. Macro- and micromorphology were analyzed following procedures detailed by Miller \& Miller (1988). Color names and codes (in parenthesis) followed Kornerup \& Wanscher (1978) for macroscopic features, while colors in microstructures are under $5 \% \mathrm{KOH}$ observations. Measurements of 25 elements each (mature basidiospores, capillitiums, hyphae) were considered under $5 \% \mathrm{KOH}$. All presented line drawings, except for basidiomata, were made with the aid of a light tube attached to the light microscope (LM). Scanning electron microscopy (SEM) was performed following previously described methods (Cortez et al. 2008b). All collected specimens are deposited in the ICN herbarium (Universidade Federal do Rio Grande do Sul, Instituto de Biociências). 


\section{Results}

\section{Lycoperdon Pers.}

The largest genus in Lycoperdaceae, with ca. 50 species worldwide (Kirk et al. 2008). In a strict sense, comprises species with a well-developed sterile base, gleba without (or scarce) paracapillitium, and without a distinct diaphragm. Several names have been reported from other Brazilian regions than Rio Grande do Sul, including many synonyms and misidentifications which require further review. A preliminary checklist of Brazilian Lycoperdon is found in Baseia (2005).

\section{Key to the species of Lycoperdon from Rio Grande do Sul, Brazil}

1. Exoperidium distinctly spiny, composed by conspicuous conical or pyramidal spines ............... 2

1. Exoperidium granulose, velutinous or asperulate ......................................................... 3

2. Spines of exoperidium pyramidal, falling in plates to expose the smooth endoperidium, mature basidiospores smooth to punctuate under LM

3. L. marginatum

2. Spines of exoperidium conical and with rounded apex, which leave scars forming a reticulate pattern on the endoperidium surface, basidiospores verrucose to echinate under LM . 5. L. perlatum 3. Basidiospores ovoid, smooth under LM 4. L. ovoidisporum

3. Basidiospores globose to subglobose, smooth to echinate or verrucose ................................ 4

4. Basidiospores smooth (LM), exoperidium hyphae versiform ..................................... 2. L. lividum

4. Basidiospores echinate, exoperidium formed by setoid hyphae

1. L. juruense

Lycoperdon juruense P. Henn., Hedw. 43: 184 (1904).

Figs. 1, 7-10, 37

Basidiomata 25-40 mm diam., 34-43 mm high, broadly pyriform, with a well-developed sterile base and numerous rhizomorphs attached to substrate. Exoperidium yellowish brown (5F6) to greyish brown (5F3), shiny, formed by small spines $(<0.2 \mathrm{~mm}$ high), velvety when fresh, roughly granulose to asperulate when dried. Endoperidium papery, dull yellowish brown (5D5-5E5) at maturity, dehiscing by a small, central circular peristome. Gleba immature white (5A1), soon becoming greyish brown (5E3) to finally brown (5F4) at maturity, cottony. Sterile base 6-16 mm high, gradually differentiated from gleba, loculate to compact in some specimens, white (5A1) when immature to brownish grey (5E4) at age. Rhizomorphs $<2 \mathrm{~mm}$ thick, white (2A1), scattered to numerous. Basidiospores 3.4-5(-6) $\mu \mathrm{m}$ diam. (including ornamentation), globose, with a very short pedicel $(<0.5 \mu \mathrm{m}$ long), long pedicels are rarely observed, pale brown, densely echinate under LM, under SEM the ornamentation is formed by broad and low warts, solitary or with connivent tips. Eucapillitium 3.4-7 $\mu \mathrm{m}$ diam., Lycoperdon-type, walls smooth, thick and without pores and septa, yellowish brown. Paracapillitium absent. Exoperidium formed of pyramidal aggregates of setoid elements (mycosclereids), 18.5-63 × 8.5-25 $\mu \mathrm{m}$, with smooth and thick walls $(1.7-4 \mu \mathrm{m}$ diam.), subcylindrical, subclavate, subglobose, fusiform, pale brown.

Habitat - on soil and litter in subtropical forest, also in meadows near to forest edges.

Known distribution - Neotropical (Demoulin 1976). Brazil: known from the states of Amazonas (Demoulin 1976), Goiás (new record) and Rio Grande do Sul (Rick 1961).

Material examined - Brazil. Rio Grande do Sul State: Arroio do Padre, RS 737, 15 Feb 2008, V. G. Cortez 021/08 (ICN 154558). Itaara, Parque Pinhal, 11 May 2006, V.G. Cortez 044/06 (ICN 154559). Porto Alegre, Assunção, 01 June 1972, B.E. Irgang \& L.R.M. Baptista (ICN 6354); Morro da Polícia, M.H. Homrich (ICN 3605). Santa Maria, 1935, J. Rick (PACA 13773, as L. atropurpureum); Morro do Elefante, 23 June 2006, V.G. Cortez 059/06 (ICN 154560). São Leopoldo, 1907, J. Rick (PACA 13788). Viamão, Schoenwald, 03 June 1970, F. Schoenwald (ICN 6132). Additional specimen - Brazil. Goiás State: Brockes (PACA 13791, as L. nigrescens).

Notes - This Neotropical Lycoperdon is similar to L. umbrinoides Dissing \& Lange, known from Africa (Dissing \& Lange 1962), Spain (Calonge et al. 2000), Japan (Kasuya 2004) and Italy (Sarasini 2005). The difference among both species is the exoperidium structure, which is composed of chains of thin-walled $(<2 \mu \mathrm{m})$ hyphae in L. umbrinoides (Demoulin 1976), and also present a distinct geographical distribution (Calonge et al. 2000). 


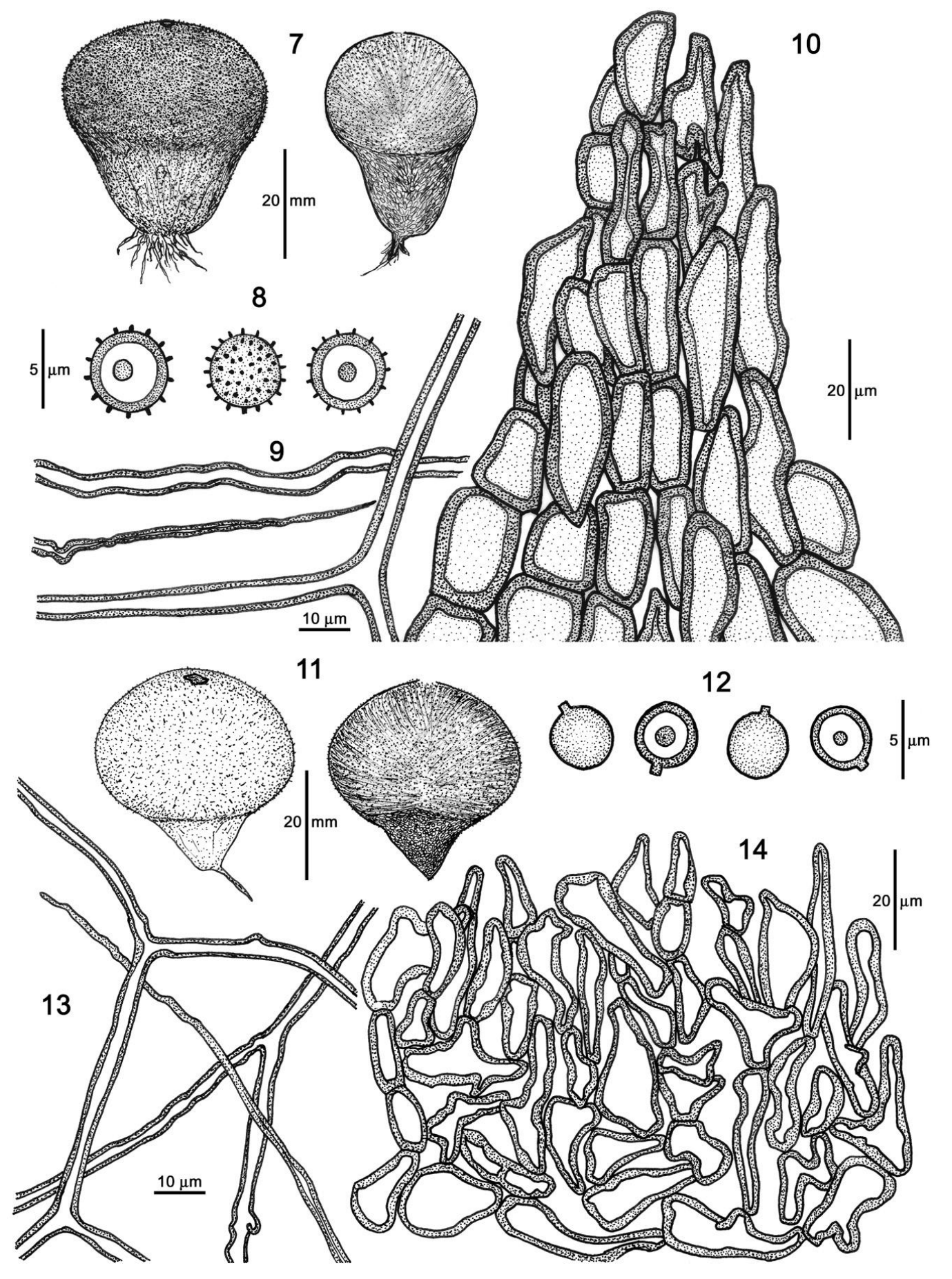

Figs 7-10 Lycoperdon juruense: 7 Basidiomata. 8 Basidiospores. 9 Eucapillitium 10 Exoperidium hyphae. Figs 11-14 Lycoperdon lividum: 11 Basidiomata. 12 Basidiospores. 13 Eucapillitium. 14 Exoperidium hyphae.

Further comparison between Neotropical and Old World specimens is required to elucidate their relationships. Lycoperdon atrum Pat. 1902 was considered synonymous with L. juruense by Demoulin (1976), but the name is unavailable because its holotype has been lost; moreover, it is an illegitimate name (Art. 53.1) and posterior homonym for L. atrum Schaeff. 1774, which is considered a synonym of the xylariaceous ascomycete Daldinia concentrica (Bolton) Ces. \& De Not. In Brazil, L. juruense is known from Amazonas to southern Brazil, and among Rick's 
materials, it was found a collection misidentified as L. nigrescens from Goiás (Central Brazil), from where it is recorded for the first time.

Lycoperdon lividum Pers., J. Bot., Paris 2: 18 (1809).

Figs. $11-14,38$

Basidiomata 21-40 mm diam., 15-39 $\mathrm{mm}$ high, subpyriform to subglobose, with a distinct sterile base and scattered rhizomorphs. Exoperidium light orange (5A5) to greyish orange (5B5), velutinous to granulose, formed by thin and small-sized spines $(<0.3 \mathrm{~mm}$ long), deciduous with age. Endoperidium light brown (5D5) to yellowish brown (5D8), smooth to lanose, dehiscence through an irregular peristome. Gleba pulverulent to sublanose, olive brown (4D7). Sterile base cellular to subcompact, $<17 \mathrm{~mm}$ high, greyish orange (5B4). Rhizomorphs scattered, thin and short, white (5A1). Basidiospores 3.4-4.6 $\mu \mathrm{m}$ diam. (including ornamentation), globose, smooth to subtle punctuate under LM, under SEM, small, scattered and rounded warts are seen, short pedicel $(<0.5$ $\mu \mathrm{m}$ long) present, pale yellow. Eucapillitium 2.5-5 $\mu \mathrm{m}$ diam., of Lycoperdon-type, walls smooth, sometimes wavy and thick, with small to large $(<3.4 \mu \mathrm{m}$ diam.) pores, septa rare, dichotomously branched, yellow. Paracapillitium absent. Exoperidium formed by fairly chained versiform hyphae (pyriform, elliptical, clavate, subfusoid), 10-36 × 6-17 $\mu \mathrm{m}$, with thick walls $(<2.5 \mu \mathrm{m}$ diam.), hyaline to greenish yellow.

Habitat - on soil and litter in subtropical forest.

Known distribution - Australasia, Europe, North and South America (Bates et al. 2009). In Brazil it is only known from Rio Grande do Sul.

Material examined - Brazil. Rio Grande do Sul State: São Salvador, 17 Jan 1944, J. Rick (PACA 20701). Viamão, Parque Estadual de Itapuã, 10 Sep 2005, R.M. Silveira (ICN 154631); Schoenwald, 09 Aug 1966, Schoenwald (ICN 4079).

Notes - This species was found in Rick's herbarium, misidentified as L. umbrinum, but the features of the specimen fits well in the literature (Calderón-Villagómez \& Pérez-Silva 1989, Bates et al. 2009). Moreover, the spiny exoperidium and more ornamented basidiospores of L. umbrinum clearly distinguish it from L. lividum (Bates et al. 2009). The terrestrial habitat, granulose and yellowish exoperidium, composed of variably-shaped setoid hyphae, and the smooth to punctuate basidiospores are important features for the identification of L. lividum. Lycoperdon umbrinum is similar to L. nigrescens, reported from Brazil but, up to now, not reported from Rio Grande do Sul (Baseia 2005), and differs in the reticulate endoperidium of the latter (Calonge 1998).

Lycoperdon marginatum Vittad., Monogr. Lycoperd.: 41 (1842).

Figs. 2, 15-19, 39

Basidiomata 19-47 mm diam., 20-42 mm high, pyriform to depressed-subglobose, with a reduced to well-developed sterile base and a rooting base, growing solitary or in small groups. Exoperidium composed by large pyramidal spines $(<2.5 \mathrm{~mm}$ high), white (4A1) when young to greyish yellow (4B4) when old or dried, with connivent tips, which falls away in plates, exposing the endoperidium. Endoperidium white (4A1) in earlier stages, then becoming brownish yellow (5C7) to golden brown (5D7) at maturity, smooth to asperulate. Gleba white (4A1), turning to greyish green (1C6) and finally olive brown (4E8) at maturity, pulverulent. Sterile base 9-27 mm high, spongy, loculate, white (3A1) to olive (3D5) with maturity. Rhizomorphs scarce, but a central and larger rhizomorph (pseudorrhiza) is present, white (2A1), <2.5 mm thick. Basidiospores 3.5-5 $\mu \mathrm{m}$ diam., globose, smooth to minutely punctuate under LM, with a delicate ornamentation when examined under SEM, which is composed by small warts connected by a thin reticulum, shortly pedicellate $(<1.5 \mu \mathrm{m}$ long), pale green. Eucapillitium (2.5-) 4-9 (-12) $\mu \mathrm{m}$ diam., Lycoperdon-type, walls thick, smooth and undulating, with scattered but large pores, tapering gradually or abruptly, yellowish brown. Paracapillitium 2.5-4.2 $\mu \mathrm{m}$ diam., with thin and smooth walls, hyaline, septate, unbranched, scarce. Exoperidium two-layered: outer layer pseudoparenchymatic, composed by hyaline, thin walled hyphae, $13.5-44 \times 7-20 \mu \mathrm{m}$, irregular in shape, but mainly pyriform to clavate; inner layer near the endoperidium formed by setoid elements (mycosclereids), 38.5-86 × 19.5-52 $\mu \mathrm{m}$, smooth and thick-walled ( $2-3 \mu \mathrm{m}$ diam.), subelliptical to subglobose, pale yellow.

Habitat - on soil, among grasses, in meadows or forest edges. 
Known distribution - widespread in all continents, but mostly cited in the Americas (Ponce de Leon 1970). Brazil: known from the states of São Paulo (Bononi et al. 1984), Paraná (Meijer 2006), Santa Catarina (new record) and Rio Grande do Sul (Rick 1961, Sobestiansky 2005).

Material examined - Brazil. Rio Grande do Sul State: Cambará do Sul, Parque Nacional dos Aparados da Serra, 07 Dec 2006, V.G. Cortez 088/06 (ICN 154572). Capão da Canoa, 08 Aug 1973, J. Lindeman (ICN 6394). Cerro Azul, 1935, J. Rick (PACA 13794, as L. stellatum). Guaíba, Fazenda São Maximiliano, 02 July 2006, L.F.P. Lima (ICN 154565). Itaara, Parque Pinhal, 11 May 2006, V.G. Cortez 048/06 (ICN 154570). Lavras do Sul, BR 357, 16 Feb 2008, V.G. Cortez 024/08 (ICN 154561). Pelotas, IAS, E.C. Santos 109 (PEL 2811). Pinhal, 30 May 1970, F.R. Schoenwald (ICN 6110). Rio Grande, Campus Carreiros FURG, 23 June 1988, A. Görgen (HURG 3351), 03 Dec 1991, L.F.M. Neves (HURG 3701), 16 June 1992, M.S. Farias (HURG 3761), 29 Sep 1993, C.M. Abreu (HURG 3014), Country Club, 15 June 1992, M.S. Farias (HURG 3755), Jardim do Sol, 11 July 1990, V.L.N. Susin (HURG 3547), 04 Oct 1993, C.M. Abreu (HURG 3022), 13 Dec 1993, leg. C.M. Abreu (HURG 3151), Marisma, 27 Aug 1990, M.S. Farias (HURG 3556), Querência, 17 July 1992, T.S. Gonzalez (HURG 3793). Salvador do Sul, 1942, leg. J. Rick (PACA 12525), 18 Jan 1944, J. Rick (PACA 20848, as L. wrightii), Nov 1945, J. Rick (PACA 20619). Santa Cruz do Sul, 06 June 2008, V.G. Cortez 103/08 (ICN 154562). Santa Maria, Estação Experimental de Silvicultura - FEPAGRO, 03 Mar 2007, G. Coelho (ICN 154563); Morro da Caturrita, 02 May 2006, V.G. Cortez 032/06 (ICN 154569), 26 May 2009, G. Coelho (ICN 154564). São Francisco de Paula, Alpes de São Francisco, 04 Apr 2008, L.F.P. Lima (ICN 154566); FLONA, 1981, R.T Guerrero (ICN 56074); Veraneio Hampel, 08 Apr 2006, V.G. Cortez 009/06 (ICN 154568). São Leopoldo, 1906, J. Rick (PACA 12527), 1929, J. Rick (PACA 12533), 1933, J. Rick (PACA 12534), 1935, J. Rick (PACA 12532), 1940, J. Rick (PACA 12522). Torres, 12 Nov 1968, M.L. Porto (ICN 5710). Uruguaiana, 14 Oct 2008, G.B. Ceolin (ICN 154567). Additional specimens - Brazil. Santa Catarina State: Araranguá, Morro dos Conventos, 16 Nov 1968, M.L. Porto (ICN 5705), 18 Nov 1969, L.R.M. Baptista et al. (ICN 6099). Bom Jardim da Serra, margin Rio Pelotas, 06 Dec 2006, V.G. Cortez 083/06 (ICN 154571, dupl. at UFRN-Fungos). Garopaba, 12 Apr 1968, F. Flores (ICN 6014).

Notes - Lycoperdon marginatum is a common grassland species in southern Brazil, where it has been found in native meadows, gardens and forest edges, among grasses. The diagnostic feature of the species is the pyramidal spiny exoperidium that falls away in plates at maturity, exposing a smooth and pale brown endoperidium. Other Lycoperdon and Vascellum have similar exoperidium but differ in other features (diaphragm, capillitium, sterile base, basidiospores). Rick (1961) reported it as Calvatia cruciata and Bononi et al. (1984) as L. candidum, both considered synonyms of the species (Demoulin 1976). Guzmán (2008, as L. candidum) considers the species edible and medicinal in Mexico, while Heim \& Wasson (1965) referred it as probably hallucinogenic puffball.

Lycoperdon ovoidisporum Cortez, Baseia \& R.M. Silveira, Sydowia 63: 2 (2011). Figs. 3, 20-23, 40, 41

Description - see Cortez et al. (2011a).

Habitat - on soil and litter in subtropical forest.

Known distribution - only known from type locality, Rio Grande do Sul, in southern Brazil.

Material examined - Brazil. Rio Grande do Sul State: Santa Maria, Campus UFSM, 22 Aug 2006, V.G. Cortez 066/06 (ICN 154575); Cerrito, 28 May 2007, V.G. Cortez 109/07 (ICN 154573, holotype); Estação Experimental de Silvicultura, FEPAGRO, 25 Feb 2009, G. Coelho (ICN 154577); Morro da Caturrita, 27 Apr 2006, V.G. Cortez 023/06 (ICN 154574); Morro Mariano da Rocha, 23 March 2007, V.G. Cortez 031/07 (ICN 154576). São Leopoldo, J. Rick (PACA 13805, as L. brasiliense Speg.), 1931, J. Rick (PACA 13771, as L. cupricum Bonord.). Viamão, Parque SaintHilaire, 14 Mar 1975, M.H. Homrich (ICN 6434).

Notes - This recently described species (Cortez et al. 2011a) was based on the following features: pyriform basidiomata, olivaceous to olivaceous-brown gleba, and remarkable brown ovoid 
basidiospores, which are smooth under LM, but verrucose to subnodulose ornamented when examined under SEM. Basidiospore shape is considered a diagnostic feature because only a few Lycoperdon species are known to have ovoid basidiospores. Full description and comparison with similar taxa is found in Cortez et al (2011a). Rick (1961) recorded this species from Rio Grande do Sul as L. brasiliense and L. cupricum, respectively synonyms of Calvatia rugosa (Berk. \& M.A. Curtis) D.A. Reid (Reid 1977, Cortez et al. 2012) and L. molle Pers. (Demoulin 1970).

Lycoperdon perlatum Pers., Syn. Meth. Fung.: 145 (1801).

Figs. 4, 24-27, 42

Basidiomata 19-46 mm diam., 25-52 $\mathrm{mm}$ high, pyriform to turbinate, umbonate, pseudostipitate due to a well-developed sterile base and numerous rhizomorphs attached to substrate (litter and also much decomposed wood). Exoperidium echinate, formed by conical, medium-sized spines $(<1.5 \mathrm{~mm}$ high), color variable, from white $(5 \mathrm{~A} 1)$ to grey $(5 \mathrm{~B} 1-5 \mathrm{C} 1)$ and greyish brown (5F3) at the umbo, the spines are deciduous with age. Endoperidium brownish orange (5C3) to yellowish brown (5D5), surface reticulate after fall of the spines of exoperidium and becoming less conspicuous in oldest basidiomata, dehiscence through a wide circular, central peristome. Gleba white (5A1) when immature, becoming yellowish brown (5E6) at maturity, strongly pulverulent. Sterile base well-developed, forming a pseudostipe, 11-27 mm high, loculate, white (5A1) when young to greyish brown (5D3) in older specimens. Rhizomorphs $<0.5 \mathrm{~mm}$ thick, long, white (5A1), abundant. Basidiospores 3.2-4.8 $\mu \mathrm{m}$ diam. (including ornamentation), globose, echinulate under LM, the spines are blunt when seen under SEM, and interconnected by means of a filamentous reticulum, a very short pedicel $(<0.5 \mu \mathrm{m}$ long $)$ is present, pale yellow. Eucapillitium $3-$ $7.5 \mu \mathrm{m}$ diam., of Lycoperdon-type, walls smooth or with hyaline incrustation, thick and without pores, yellowish brown. Paracapillitium scarce, limited to peripheral region of the gleba, 3.5-5.5 $\mu \mathrm{m}$ diam., smooth and thin-walled, septate, little branched, hyaline. Exoperidium composed by chains of sphaerocysts, $12.5-34 \times 9.5-25 \mu \mathrm{m}$, with slightly thickened walls $(<1.7 \mu \mathrm{m}$ diam. $)$, shape pyriform, elliptical or mostly subglobose, pale brownish.

Habitat - on soil, litter and much rotten wood, in subtropical forest.

Known distribution - cosmopolitan (Sarasini 2005). Brazil: states of Pernambuco (Baseia 2005), São Paulo (Bononi et al. 1981) and Rio Grande do Sul (Cortez et al. 2008a).

Material examined - BRAZIL. Rio Grande do Sul State: Boqueirão do Leão, Perau da Nega, 17 Mar 2008, M.A. Sulzbacher 143 (ICN 154591). Gravataí, Morungava, 21 Apr 1965, M.H. Homrich (BAFC 32104). Itaara, Parque Pinhal, 11 May 2006, V.G. Cortez 047/06 (ICN 154579); 25 Jan 2007, V.G. Cortez 004/07 (ICN 154579), 010/07 (ICN 154589). Porto Alegre, Parque Saint Hilaire, 30 Apr 1960, D.M. Dring (SP 61712), May 1995, R.T. Guerrero \& R.M.B. Silveira (ICN 102578). Santa Maria, Arroio do Só, 17 June 2003, V.G. Cortez 031/03 (SMDB 9628); Estação Experimental de Silvicultura - FEPAGRO, 15 May 2007, V.G. Cortez 095/07 (ICN 154588), 02 March 2009, G. Coelho (ICN 154584); Morro Mariano da Rocha, 23 March 2007, V.G. Cortez 033/07 (ICN 154587); Morro do Elefante, 13 Feb 1997, G. Coelho 88-6 (ICN 154585), 20 Apr 2001, G. Coelho 291-2 (ICN 154586), 24 Apr 2004, V.G. Cortez 007/04 (SMDB 9717). Santana da Boa Vista, 03 Sept 2008, M. Molz (ICN 154590). Sapiranga, Picada Verão, 21 Oct 1995, M.L. Krever-57 (ICN ex HASU 4817), 28 Oct 1996, A. Silva Jr. (ICN ex HASU 5806). Sarandi, Linha Bonita, 08 Aug 2008, M.S. Rother (ICN 154592). São Francisco de Paula, FLONA, 07 Oct 2006, P.S. Silva (ICN 154583), 01 June 2007, P.S. Silva (ICN 154582), 30 June 2007, P.S. Silva (ICN 154581); CPCN Pró-Mata, PUCRS, 24 May 2009, G. Coelho (ICN 154580). São Leopoldo, 1929, B. Braun (PACA 13789), 1930, J. Rick (PACA 13774, as L. nigrescens). Viamão, Parque Estadual de Itapuã, 22 May 2004, V.G. Cortez 025/04 (ICN). Additional specimen - Uruguay. Montevideo, Herter (PACA 13795).

Notes - This forest taxon is very common in the study area, where it grows on litter and very rotten wood, including exotic and native forests. It is a cosmopolitan species, reported from all continents (Sarasini 2005). Lycoperdon perlatum is distinguished from other species by the conical 


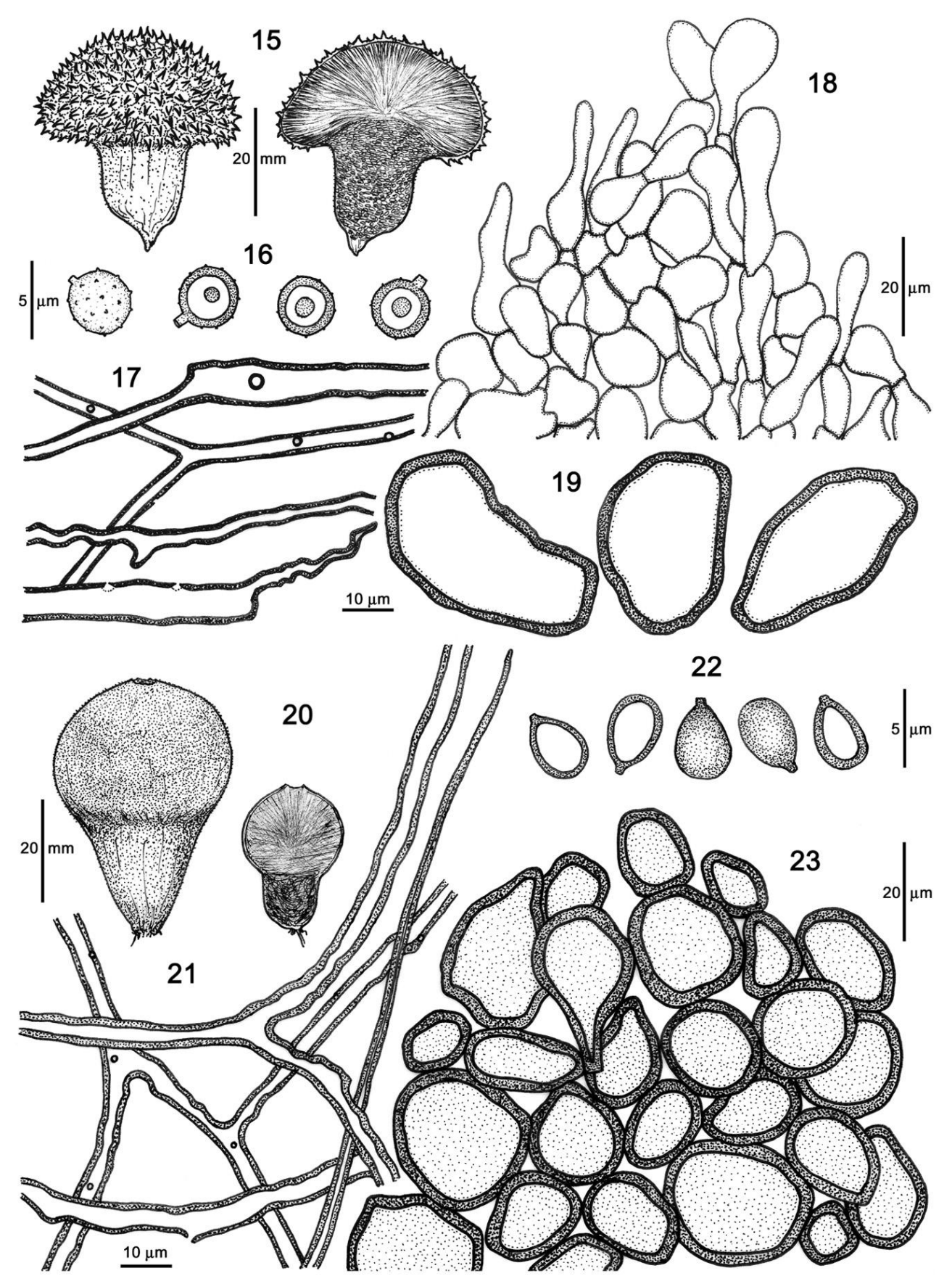

Figs 15-19 Lycoperdon marginatum: 15 Basidiomata. 16 Basidiospores. 17 Eucapillitium 18 Exoperidium hyphae. 19 Mycosclereids. Figs 20-23 Lycoperdon ovoidisporum: 20 Basidiomata. 21 Eucapillitium. 22 Basidiospores. 23 Exoperidium hyphae.

spines of the exoperidium, reticulate endoperidium, pyriform substipitate basidiomata, and echinulate basidiospores. The species is very variable, comprising distinct color tones and ornamentation of the exoperidium, basidioma size, shape and extension of subgleba and sterile base; it is possible that future phylogenetic studies prove to represent a complex of morphologically closely related taxa of worldwide occurrence. Rick (1961) reported it as L. gemmatum from Rio Grande do Sul state and Meijer (2006) cited L. pseudogemmatum Speg. (a possible synonym) from Paraná. It is another puffball considered as edible when immature (Guzmán 2008). 


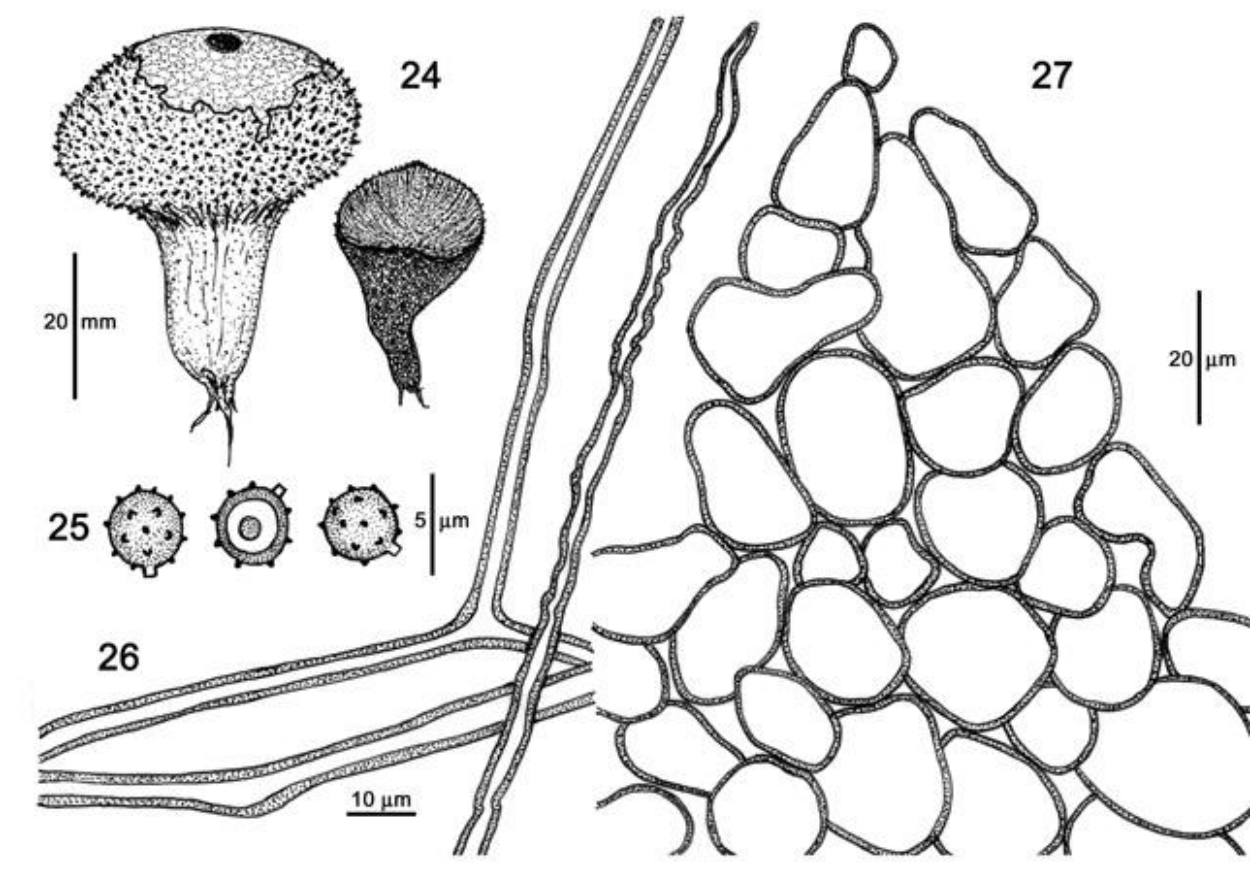

Figs 24-27 Lycoperdon perlatum: 24 Basidiomata. 25 Basidiospores. 26 Eucapillitium 27 Exoperidium hyphae.

\section{Other records of Lycoperdon by Rick (1961)}

- L. acuminatum = the material (BRAZIL. RIO GRANDE DO SUL: São Leopoldo, 1906, J. Rick, PACA 13777) belongs to Morganella, but the poor conditions does not allowed the specific identification.

- L. atropurpureum $=$ misidentification of $L$. juruense (see discussion above).

- L. benjaminii (as 'beniamin') Rick = Morganella benjaminii (Rick) Cortez, Calonge \& Baseia, see Cortez et al. (2007).

- L. brasiliense, L. fuscum, L. tropicale = misidentifications of Calvatia rugosa (Cortez et al. 2012).

- L. cupricum $=$ L. ovoidisporum, see above.

- L. foliicolum Rick, L. proximum Rick, L. rarum Rick = doubtful names because types or specimens are not preserved.

- L. fuligineum, L. subincarnatum = misidentifications of the Neotropical puffball Morganella fuliginea (Berk. \& M.A. Curtis) Kreisel \& Dring.

- L. gemmatum $=$ L. perlatum, see discussion above.

- L. nigrescens $=$ misidentifications of $L$. juruense and L. perlatum (see discussion above).

- L. oblongisporum = Bovista capensis (Fr.) J.C. Coetzee \& A.E. van Wyk.

- L. pedicellatum $=$ B. dominicensis (Massee) Kreisel.

- L. pulcherrimum $=$ the preserved material (BRAZIL. RIO GRANDE DO SUL: São Leopoldo, 1929, J. Rick, PACA 13776) is immature.

- L. pusillum = Bovista aestivalis (Bonord.) Demoulin.

- L. pyriforme $=$ Morganella pyriforme (Pers.) Krüger \& Kreisel (Krüger \& Kreisel 2003).

- L. stellatum $=$ L. marginatum (see above).

- L. subpratense $=$ no specimens preserved.

- L. wrightii $=$ Rick's materials labelled under this name are: Morganella sp. (PACA 13812), B. dominicensis (PACA 13790) and L. marginatum (see above). 


\section{Vascellum F. Šmarda}

A segregated genus from Lycoperdon due to the presence of a membrane separating the gleba and subgleba (diaphragm) and presence of paracapillitium. However, some species develop a pseudodiaphragm, while others present both eucapillitium and paracapillitium (Homrich \& Wright 1988). World revisions of the genus were published by Ponce de Leon (1970) and Kreisel (1993), and a very detailed study of South American taxa was presented by Homrich \& Wright (1988). In Brazil, the following species were reported: $V$. curtisii, $V$. endotephrum $(=V$. vanderystii), $V$. hyalinum, $V$. lloydianum ( $=V$. subpratense), $V$. pratense, and $V$. texense. In the key below, $V$. curtisii is included because the species was recorded from Rio Grande do Sul (Homrich \& Wright 1988), although we have not studied materials form this species.

\section{Key to the species of Vascellum from Rio Grande do Sul, Brazil}

1. Only paracapillitium present

6. V. hyalinum

1. Paracapillitium and eucapillitium present V. curtisii

2. Exoperidium formed by subglobose, slightly thick-walled hyphae 7. V. pratense

Vascellum hyalinum Homrich, Can. J. Bot. 66: 1296 (1988).

Figs. 5, 28-31, 43

Basidiomata 11-23 mm diam., 9-18 mm high, depressed subglobose to globose, with a small sterile base and a few basal rhizomorphs attached to substrate, growing densely gegarious or in groups of up to 5 basidiomata. Exoperidium furfuraceous to spiny in young specimens, composed by minute spines $(<0.2 \mathrm{~mm}$ high), color reddish grey (7B2) to dark brown (7F8), at maturity the spines become areolate forming small dark brown (7F8) scales to finally fall away. Endoperidium pinkish white (7A1) to light brown (5D5) at maturity, papery and smooth, opening by an irregular peristome. Gleba white (4A1) at first, becoming olive brown (4E7) and much pulverulent when mature. Diaphragm present, but very thin $(<0.2 \mathrm{~mm})$, separating the gleba from subgleba. Sterile base 3-6 mm high, poorly developed, formed by very small locules, white (5A1) when young to yellowish brown (5E5) at maturity. Rhizomorphs scarce, small and thin, white (2A1). Basidiospores 3.8-4.5 × 3.5-3.8 $\mu \mathrm{m}$, mainly subglobose with a few globose or broadly ovoid, with a small echinate ornamentation under LM, which is conspicuously formed by blunt spines under SEM, short pedicel ( $<1.5 \mu \mathrm{m}$ long) present, pale yellow. Eucapillitium absent. Paracapillitium 3.5$7 \mu \mathrm{m}$ diam., smooth and little thickened walls, septa common and frequent, hyaline. Exoperidium formed by globose, subglobose to pyriform sphaerocysts, 10-27 $\mu \mathrm{m}$ diam., walls smooth and thin ( $<1 \mu \mathrm{m}$ thick), hyaline to yellow, except for the hyphae of the scales which are brown.

Habitat - on naked soil or with scattered grasses, in open and urban places.

Known distribution - subtropical zone of Argentina and Brazil (Homrich \& Wright 1988). Brazil: only known from Rio Grande do Sul (type locality, Homrich \& Wright 1988).

Material examined - Brazil. Rio Grande do Sul State: Guaíba, Estação Experimental UFRGS, 07 Jan 1972, J.P. Costa Neto (BAFC 51655, isotype). Santa Maria, Dores, 22 Feb 2009, V.G. Cortez 004/09 (ICN 154481), 23 Feb 2009, V.G. Cortez 007/09 (ICN 154482), 04 March 2009, V.G. Cortez 009/09 (ICN 154483).

Notes - This is a native member of Vascellum, described by Homrich \& Wright (1988) based on specimens from Rio Grande do Sul. The small specimens occur in meadows, urban gardens and grasslands, in denuded soil, especially in the summer months. The diaphragm is very inconspicuous, but the exclusive presence of paracapillitium and the terricolous habit supports its placement in Vascellum. 

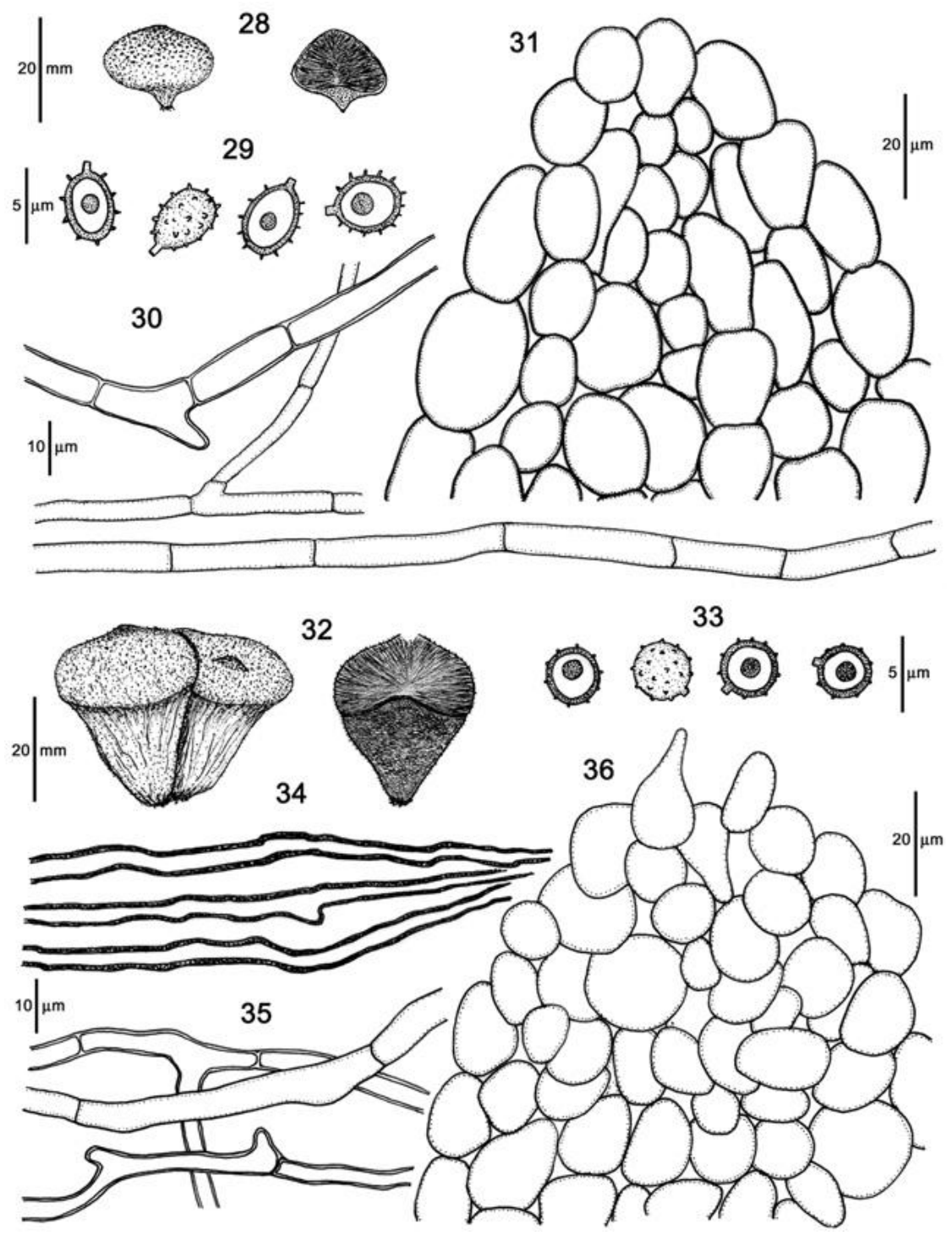

Figs 28-31 Vascellum hyalinum: 28 Basidiomata. 29 Basidiospores. 30 Paracapillitium 31 Exoperidium hyphae. Figs 32-36 Vascellum pratense: 32 Basidiomata. 33 Basidiospores. 34 Eucapillitium. 35 Paracapillitium. 36 Exoperidium hyphae.

Vascellum pratense (Pers.) Kreisel, Feddes Repert. 64: 159 (1962).

Figs. 6, 32-36, 44

Basidiomata 22-38 mm diam., 20-31 mm high, depressed subglobose to pyriform, with a well-developed, slightly marginate sterile base and a few rhizomorphs, gregarious or in groups of 2-3 basidiomata. Exoperidium white (2A1) to olive brown (4D8) composed by small spines ( $<0.5$ $\mathrm{mm}$ high), giving a furfuraceous to granulose aspect in younger specimens, falling away with age. Endoperidium white (2A1) to blond (4C4) to finally olive brown (4D5) at maturity, smooth, opening through a wide central and apical peristoma. Gleba white (2A1) in young stage, becoming greyish yellow (2C3) to finally olive brown (4E8) at maturity, pulverulent. Diaphragm present, about $1 \mathrm{~mm}$ thick, separating the gleba from subgleba. Sterile base $15-21 \mathrm{~mm}$ high, loculate, yellowish white (2A2) to blond (4C) in older specimens. Rhizomorphs $<0.5 \mathrm{~mm}$ thick, white (2A1), scarce. Basidiospores 3.4-4.2 $\mu \mathrm{m}$ diam., globose, with a punctuate ornamentation under LM, which is formed of rounded verrucae and short and broad spines, sometimes connected by thin filaments, when observed under SEM, short pedicellate $(<1 \mu \mathrm{m}$ long), guttulate, pale yellow. Eucapillitium 3$5 \mu \mathrm{m}$ diam., of Lycoperdon-type, walls smooth, thick and with rare small pores, yellowish brown. Paracapillitium 3.5-7 $\mu \mathrm{m}$ diam., with smooth and slightly thickened walls, septa common, little branched, hyaline. Exoperidium formed by globose, subglobose, broad elliptical or pyriform sphaerocysts, 9-26 $\mu \mathrm{m}$ diam., with thin walls ( $<1 \mu \mathrm{m}$ thick), pale greenish. 

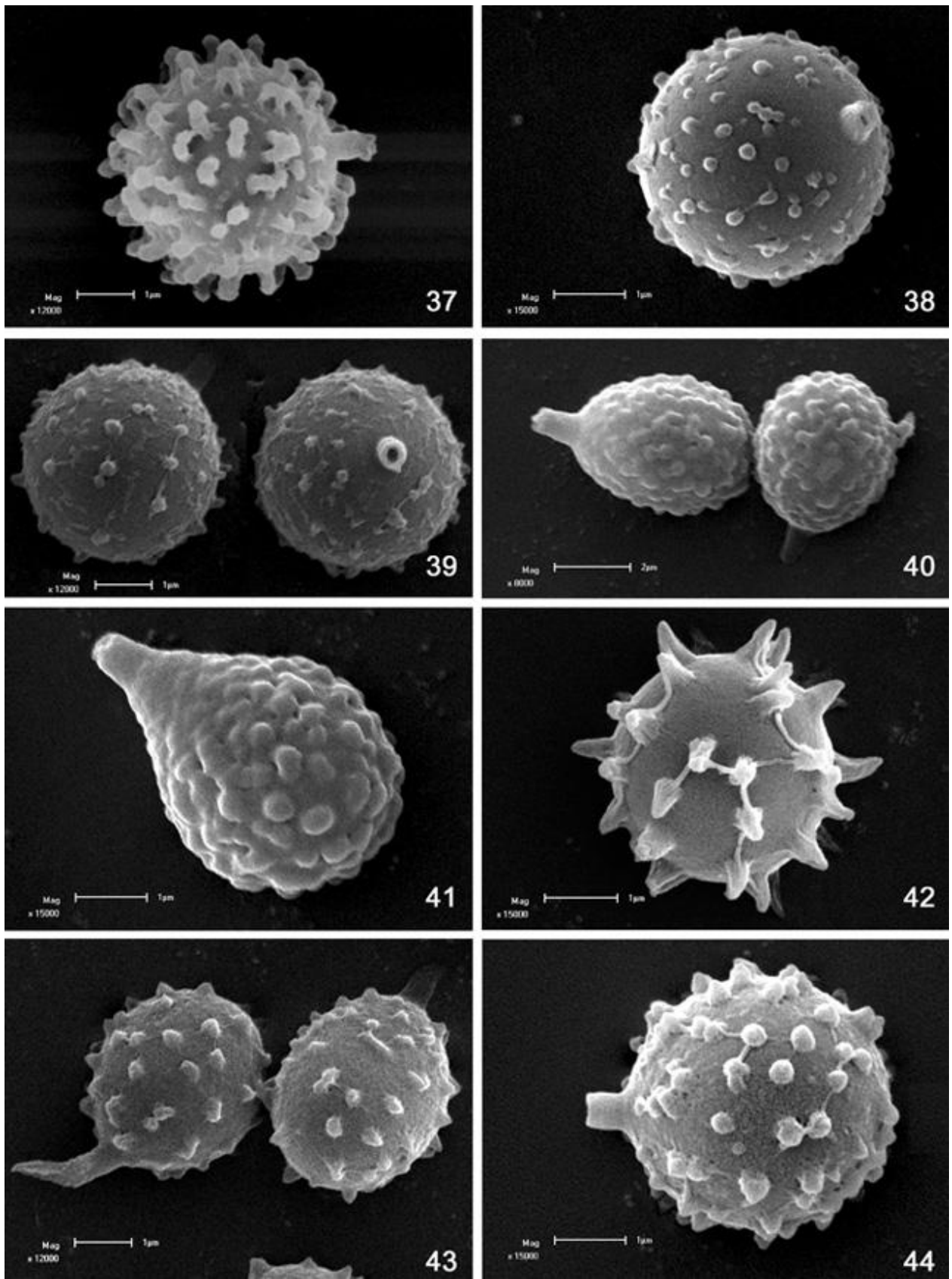

Figs 37-44 - Basidiospores under SEM. 37 Lycoperdon juruense. 38 L. lividum. 39 L marginatum. 40, 41 L. ovoidisporum. 42 L. perlatum. 43 Vascellum hyalinum. 44 V. pratense.

Habitat - on soil and litter in shady places, among grasses near subtropical forest.

Known distribution - cosmopolitan (Kreisel 1993). Brazil: known from the States of São Paulo (Bononi et al. 1984) and Rio Grande do Sul (Cortez et al. 2008a).

Material examined - Brazil. Rio Grande do Sul State: Santa Maria, UFSM, 05 March 2009, G. Coelho (ICN 154485), 06 March 2009, V.G. Cortez 010/09 (ICN 154484); Morro Mariano da Rocha, 18 June 1997, C.C. Faccin \& G. Coelho 98-26 (ICN 154486). Sapiranga, Picada Verão, 04 June 1988, A. Silva Jr. \& J. Larocca (ICN ex HASU 1260). Viamão, Parque Estadual de Itapuã, 22 May 2004, V.G. Cortez 026/04 (ICN); Schoenwald, 22 May 1970, F.R. Schoenwald (ICN 6092).

Notes - This is the most widespread species of Vascellum, reported from all continents (except Antarctica), as discussed by Kreisel (1993). In Rio Grande do Sul, it was collected in soil and near native forests, showing evidence of a likely introduction. It is considered an edible fungus when immature (Guzmán 2008). 


\section{Acknowledgements}

The authors thank Dr. Gilberto Coelho (Universidade Federal de Santa Maria, Brazil) for providing specimens and photos, and CNPq (Brazil) for financial support.

\section{References}

Baseia IG. 2005 - Some notes on the genera Bovista and Lycoperdon (Lycoperdaceae) in Brazil. Mycotaxon 91, 81-86.

Bates ST, Roberson RW, Desjardin DE. 2009 - Arizona gasteroid fungi I: Lycoperdaceae (Agaricales, Basidiomycota). Fungal Diversity 37, 153-207.

Bononi VLR, Guzmán G, Capelari M. 1984 - Basidiomicetos do Parque Estadual da Ilha do Cardoso. V: Gasteromicetos. Rickia 11, 91-97.

Bononi VLR, Trufem SFB, Grandi RAP. 1981 - Fungos macroscópicos do Parque Estadual das Fontes do Ipiranga, São Paulo (SP), Brasil, depositados no Herbário do Instituto de Botânica. Rickia 9, 37-53.

Calderón-Villagómez A, Perez-Silva E. 1989 - Consideraciones taxonómicas y nuevos registros de algunas especies del género Lycoperdon (Gasteromycetes) en México. Anales del Instituto de Biología de la Universidad Nacional Autonóma de México, Série Botánica 59, 1-30.

Calonge FD. 1998 - Gasteromycetes, I. Lycoperdales, Nidulariales, Phallales, Sclerodermatales, Tulostomatales. Flora Mycologica Iberica 3, 1-271.

Calonge FD, Vidal JM, Demoulin V. 2000 - Lycoperdon umbrinoides Dissing \& Lange (Gasteromycetes), a tropical fungus present in Europe. Boletín de la Sociedad Micológica de Madrid 25, 55-58.

Cortez VG, Calonge FD, Baseia IG. 2007. - Rick's species revision 2: Lycoperdon benjaminii recombined in Morganella. Mycotaxon 102, 425-429.

Cortez VG, Baseia IG, Silveira RMB. 2008a - Gasteromicetos (Basidiomycota) no Parque Estadual de Itapuã, Viamão, Rio Grande do Sul, Brasil. Revista Brasileira de Biociências 6, 291-299.

Cortez VG, Baseia IG, Guerrero RT, Silveira RMB. 2008b - Two sequestrate cortinarioid fungi from Rio Grande do Sul, Brazil. Hoehnea 35, 513-518.

Cortez VG, Baseia IG, Silveira RMB. 2009 - Gasteroid mycobiota of Rio Grande do Sul, Brazil: Tulostomataceae. Mycotaxon 108, 365-384. <http://dx.doi.org/10.5248/108.365>

Cortez VG, Baseia IG, Silveira RMB. 2010 - Gasteroid mycobiota of Rio Grande do Sul, Brazil: Arachnion and Disciseda (Lycoperdaceae). Acta Biologica Paranaense 39, 19-27.

Cortez VG, Baseia IG, Silveira RMB. 2011a - Lycoperdon ovoidisporum sp. nov. from Brazil. Sydowia 63, 1-7.

Cortez VG, Baseia IG, Silveira RMB. 2011b - Gasteroid mycobiota of Rio Grande do Sul, Brazil: Lysuraceae. Acta Scientiarum, Biological Sciences 33, 87-92. <http://dx.doi.org/ 10.4025/actascibiolsci.v33i1.6726>

Cortez VG, Baseia IG, Silveira RMB. 2012 - Gasteroid mycobiota of Rio Grande do Sul, Brazil: Calvatia, Gastropila and Langermannia. Kew Bulletin 67, 471-482. <http://dx.doi.org/10.1007/s12225-012-9364-6>

Demoulin V. 1970 - Les specimens de Lycoperdon de Bonorden dans l'herbier de Genéve. Taxon 19, 775-778. <http://dx.doi.org/10.2307/1219290>

Demoulin V. 1976 - Species of Lycoperdon with a setose exoperidium. Mycotaxon 3, 275-296.

Dissing H, Lange M. 1962 - Gasteromycetes of Congo. Bulletin du Jardin Botanique de l'État a Bruxelles 32, 325-416.

Guerrero RT, Homrich MH. 1999 - Fungos Macroscópicos Comuns no Rio Grande do Sul - Guia para Identificação. $2^{\mathrm{a}}$ ed. Porto Alegre: Ed. UFRGS.

Guzmán G. 2008 - Hongos de Parques y Jardines y sus Relaciones con la Gente. Xalapa: Secretaria de Educación de Veracruz.

Heim R, Wasson RG. 1965 - Les Lycocoperdons Narcotiques des Mixtèques. Archives du Muséum d'Histoire Naturelle 9, 195-199. 
Homrich MH. 1969 - Etude de quelques Gastéromycetes du Rio Grande do Sul. Revue de Mycologie 34, 3-16.

Homrich MH, Wright JE. 1973 - South American Gasteromycetes. The genera Gastropila, Lanopila and Mycenastrum. Mycologia 65, 779-794. <http://dx.doi.org/10.2307/3758517>

Homrich MH, Wright JE. 1988 - South American Gasteromycetes. II. The genus Vascellum. Canadian Journal of Botany 66, 1285-1307. <http://dx.doi.org/10.1139/b88-183>

Kasuya T. 2004 - Notes on Japanese Lycoperdaceae. 1: Lycoperdon umbrinoides, a tropical fungus newly found in Japan. Mycoscience 45, 298-300. <http://dx.doi.org/10.1007/s10267-0040184-x>

Kirk PM, Cannon PF, Minter DW, Stalpers JA. 2008 - Dictionary of the Fungi. $10^{\text {th }}$ ed. Wallingford: CABI.

Kornerup A, Wanscher JH. 1978 - Methuen Handbook of Colour. $3^{\text {rd }}$ ed. London: Eyre Methuen.

Kreisel H. 1993 - A key to Vascellum (Gasteromycetidae) with some floristic notes. Blyttia 51, $125-129$.

Kreisel H, Dring DM. 1967 - An emendation of the genus Morganella Zeller (Lycoperdaceae). Feddes Repertorium 74, 109-122. <http://dx.doi.org/10.1002/fedr.19670740105>

Krüger D, Gargas A. 2008 - Secondary structure of ITS2 rRNA provides taxonomic characters for systematic studies - a case in Lycoperdaceae (Basidiomycota). Mycological Research 112, 316-330. <http://dx.doi.org/10.1016/j.mycres.2007.10.019>

Krüger D, Kreisel H. 2003 - Proposing Morganella subgen. Apioperdon subgen. nov. for the puffball Lycoperdon pyriforme. Mycotaxon 86, 169-177.

Krüger D, Binder M, Fischer M, Kreisel H. 2001 - The Lycoperdales. A molecular approach to the systematics of some gasteroid mushrooms. Mycologia 93, 947-957. <http://dx.doi.org/10.2307/3761759>

Larsson E, Jeppson M. 2008 - Phylogenetic relationships among species and genera of Lycoperdaceae based on ITS and LSU sequence data from north European taxa. Mycological Research 112, 4-22. <http://dx.doi.org/10.1016/j.mycres.2007.10.018>

Meijer AAR. 2006 - Preliminary list of the macromycetes from the Brazilian state of Paraná. Boletim do Museu Botânico Municipal (Curitiba) 68, 1-55.

Miller OK, Miller HH. 1988 - Gasteromycetes: morphological and development features with keys to the orders, families and genera. Eureka: Mad River.

Ponce de Leon P. 1970 - Revision of the genus Vascellum (Lycoperdaceae). Fieldiana, Botany 32, $109-125$.

Reid DA. 1977 - Some Gasteromycetes from Trinidad and Tobago. Kew Bulletin 31, 657-690. <http://dx.doi.org/10.2307/4119418>

Rick J. 1930 - Lycoperdineas Riograndensis. Egatea 15, 19-30.

Rick J. 1961 - Basidiomycetes Eubasidii in Rio Grande do Sul, Brasilia 6. Iheringia, Série Botânica 9, 451-480.

Sarasini M. 2005 - Gasteromiceti Epigei. Trento: Associazione Micologica Bresadola.

Smith AH. 1951 - Puffballs and their allies in Michigan. Ann Arbor: University of Michigan Press.

Sobestiansky G. 2005 - Contribution to a macromycete survey of the States of Rio Grande do Sul and Santa Catarina in Brazil. Brazilian Archives of Biology and Technology 48, 437-457. <http://dx.doi.org/10.1590/S1516-89132005000300015>

Suárez VL, Wright JE. 1996 - South American Gasteromycetes V: The genus Morganella. Mycologia 88, 655-661. <http://dx.doi.org/10.2307/3761163>

Vellinga EC. 2004 - Genera in the family Agaricaceae: evidence from ITS and nrLSU sequences. Mycological Research 108, 354-377. <http://dx.doi.org/10.1017/S0953756204009700>

Wright JE, Suárez VL. 1990 - South American Gasteromycetes IV. The genus Abstoma. Cryptogamic Botany 1, 372-383.

Zeller SM. 1948 - Notes on certain gasteromycetes, including two new orders. Mycologia 40, 639668. http://dx.doi.org/10.2307/3755316 